\title{
Relation of Steroid on Linear Growth Velocity with Biochemical Bone Markers in Children with Nephrotic Syndrome in a Teaching Hospital, Central Nepal
}

\author{
Atanu Pan, ${ }^{1}$ Debarshi Jana ${ }^{2}$ \\ ${ }^{1}$ Department of Paediatrics and Child Health, College of Medical Sciences-Teaching Hospital, Bharatpur, Chitwan, \\ Nepal, ${ }^{2}$ Department of Gynecology and Obstetrics, Institute of Post- Graduate Medical Education and Research, A.J.C. \\ Bose Road, Kolkata, West Bengal, India.
}

\begin{abstract}
Background: Nephrotic Syndrome is the clinical manifestation of glomerular diseases associated with heavy (nephrotic range) proteinuria. This study was done to compare biochemical bone markers in nephrotic children on steroid therapy and the linear growth velocity in children with nephrotic syndrome receiving steroid with that of known available reference standard for children of same age and sex groups.
\end{abstract}

Methods: A hospital based comparative study was conducted in the Department of Pediatrics, College of Medical Sciences, Bharatpur, Nepal among 40 study group and 40 comparatvie group by taking the data from 2014 to 2018

\begin{abstract}
Results: We found that in study group, the mean Vitamin D level of patients was $12.6293 \pm 3.4974$ which was low. Present study found that in study group, the mean serum Ca (Mean \pm SD) of patients was 6.8000 \pm .9672. In comparative group, the mean serum Ca (Mean \pm SD) of patients was 9.6907 \pm .9218 . Difference of mean serum Ca vs. group was statistically significant $(\mathrm{p}<0.0001)$.
\end{abstract}

Conclusions: We found that the Mean albumin significant lower in study group compared to comparative group but total cholesterol significant higher in study group. Vitamin D and calcium were low in Study group which was statistically significant.

Keywords: nephrotic syndrome; steroid on growth velocity.

\section{INTRODUCTION}

Nephrotic Syndrome is the clinical manifestation of glomerular diseases associated with heavy (nephrotic range) proteinuria. Nephrotic range proteinuria is defined as proteinuria $>3.5 \mathrm{~g} / 24 \mathrm{hr}$ or $>40 \mathrm{mg} / \mathrm{m}^{2} / \mathrm{hr}$ or a urine protein:creatinine ratio $>2$. The triad of clinical findings associated with nephrotic syndrome arising from the large urinary losses of protein are hypoalbuminemia $(<2.5 \mathrm{~g} / \mathrm{dl})$, edema and hyperlipidemia (cholesterol $>200 \mathrm{mg}$ / dl). ${ }^{1}$

Approximately $90 \%$ of children with nephrotic syndrome have idiopathic nephrotic syndrome. Idiopathic nephrotic syndrome includes multiple histologic types, in which minimal change nephrotic syndrome (MCNS) is the most common type (approximately $85 \%$ of total Study groups of nephrotic syndrome in children). More than $95 \%$ of children with minimal change disease respond to corticosteroid therapy. ${ }^{2}$ Idiopathic nephrotic syndrome is more common in boys than in girls (2:1) and most commonly appears between the ages of 2 and 6 years. However it has been reported as early as 6 months of age and throughout adulthood. $^{3}$

Growth in patients with idiopathic nephrotic syndrome is influenced by several factors. Prior to the onset of the disease, growth in children who later develop nephrotic syndrome and that in other healthy children is influenced by the same factors. On onset of the disorder, the children suffer from proteinuria caused by the increase in glomerular permeability, leading to hypoproteinemia associated with urinary loss of several substances important for homeostasis. In most Study groups, after the start of steroid therapy, proteinuria subsides quickly; however, the side effects of glucocorticoid treatment persist. ${ }^{4}$ Glucocorticoids (GC) alter growth by directly acting on the growth cartilage or via altering the levels of growth factors. Growth is an essential feature of childhood. It depends on genetic, nutritional, social and emotional factors. It is affected by chronic systemic disease. Growth follows a sigma shaped curve with a high velocity in the early postnatal

Correspondence: Dr. Atanu Pan, Department of Paediatrics and Child Health, of Medical SciencesTeaching Hospital, Bharatpur, Chitwan, Nepal. Email: atanu8k@yahoo.co.uk. Phone: +977-9806848535. Article received: 2020-01-11. Article accepted: 2020-03-23. 
period and during puberty, but a steady rate during mid-childhood. Nephrotic syndrome occurs most commonly in the age group of 2-8 years when the growth rate is at a steady state. Patients having frequent relapses and requiring repeated courses of steroids often develop steroid toxicity, including growth retardation. ${ }^{5}$

Chronic steroid treatment has long been recognized as a major risk factor for growth retardation in children. A high correlation was found between growth retardation and cumulative steroid dose. ${ }^{6}$ Loss of bone and deterioration in short term growth are dependent on the type and dose of GC and occur most prominently over the first six months of treatment. GC induced growth failure may also be due to direct effects on the growth plate. Infusion of GC into the growth plate leads to a temporary reduction in the growth rate of that leg and may disrupt the growth plate vasculature. ${ }^{7}$ High dose corticosteroid treatment causes a decrease in bone formation as shown by the changes in alkaline phosphatase level. The higher the cumulative dose of CS used the more marked the changes in biochemical bone markers. ${ }^{4}$

The aim of this study is to compare the linear growth velocity in children with nephrotic syndrome receiving steroid with that of known available reference standard for children of same age and sex groups.

\section{METHODS}

A hospital based comparative group study was conducted among 80 patients (40 study groups and 40 Comparative groups) in the Department of Pediatrics, College of Medical Sciences, Bharatpur. Study was conducted from 2014 to 2018. Study group include those children with idiopathic steroid sensitive nephrotic syndrome on steroid therapy between 2 years to 12 years of age and comparative group include those normal children without any chronic illness between 2 years to 12 years. Children of age between 2-12 age groups and who are diagnosed with nephrotic syndrome were included in this study. Children with secondary causes of nephrotic syndrome, children who are steroid resistant (defined as failure to achieve remission after 8 weeks of corticosteroid therapy) or steroid dependent (occurrence of 2 consecutive relapses during alternate days steroid therapy or within 2 weeks of its discontinuation), children on alternative therapies to corticosteroids, short stature due to other causes excepting steroid therapy and on any calcium, phosphorus or vitamin-D containing preparations was excluded from this study.

Height was measured at the point of entry then every six months till the end of study. Treatment history with steroid and steroid sparing agents was meticulously noted in the proforma during follow up. End of recruitment of new patients six months prior to completion of the study. Minimum two height measurement data six months apart was essential criteria to remain included as study subject in this study. Height was measured by a stadiometer ( 3 years to 12 years). Children younger than three years were measured on a firm horizontal platform that contains three essential components: an attached yardstick, a fixed headplate, and a movable footplate. One adult held the child's feet steady while another adult obtained the measurement. Relevant laboratory investigations were done as mentioned below and records were maintained in a performa sheet. For statistical analysis data were entered into a Microsoft excel spreadsheet and then analyzed by SPSS 24.0 and Graph Pad Prism version 5. Data had been summarized as Mean and standard deviation for numerical variables and count and percentages for categorical variables. Two-sample $t$ -tests for a difference in Mean involved independent samples or unpaired samples t-tests were used. P-value $\leq 0.05$ was considered for statistically significant.

\section{RESULTS}

We found that in study group, the mean age $($ mean \pm SD.) of patients was $6.6867 \pm 2.7751$ years (Table 1). In comparative group, the mean age (mean \pm SD.) of patients was $6.4533 \pm 2.8119$ years (Table 1). Difference of mean age vs. group was not statistically significant $(p=0.6098)$ and the mean age at diagnosis (mean \pm SD.) of patients was $5.4067 \pm 2.4143$ years (Table 1). It was found that in Study group, the mean albumin (mean \pm SD.) of patients was $2.2733 \pm 1.8598 \mathrm{mg} / \mathrm{dl}$. In comparative group, the mean albumin (mean \pm SD.) of patients was $4.4847 \pm .6601 \mathrm{mg} / \mathrm{dl}$ (Table 1). Difference of mean albumin vs. group was statistically significant $(p<0.0001)$ (Table 1). Our study showed that in study group, the mean total cholesterol (Mean \pm SD.) of patients was 332.9467 $\pm 55.2940 \mathrm{mg} / \mathrm{dl}$ (Table 1). In comparative group, the mean total cholesterol (mean \pm SD.) of patients was $166.6800 \pm 18.4707 \mathrm{mg} / \mathrm{dl}$ (Table 1). Difference of Mean total cholesterol vs. group was statistically significant $(p<0.0001)$. It was found that in study group, the mean final height (mean \pm SD.) of patients was $114.2960 \pm 18.5996 \mathrm{~cm}$ (Table 1). In comparative group, the mean final height (Mean \pm SD.) of patients was $124.8773 \pm$ $104.4226 \mathrm{~cm}$ (Table 1). Difference of mean final height vs. group was not statistically significant $(p=0.3890)$ and in study group, the mean final height difference (mean \pm SD.) of patients was $5.4613 \pm 2.4978$ (Table 1). In comparative group, the mean final height difference (mean \pm SD.) of patients was $5.3573 \pm 1.9650$. Difference of mean final height difference vs. group was not statistically significant $(p=0.7773)$. We found that according to final height difference in study 
group, 4(5.3\%) patients had $\geq-2$ to $<+2$ and 71 (94.7\%) patients had $\geq+2$. According to final height difference in comparative group, 3(4.0\%) patients had $\geq-2$ to $<+2$ and $72(96.0 \%)$ patients had $\geq+2$. Association of final height difference vs. group was not statistically significant $(\mathrm{p}=0.6986)$ (Table 1$)$ Our study showed that in study group, the mean Vitamin D (Mean \pm SD.) of patients was $12.6293 \pm$ 3.4974. In comparative group, the Mean Vitamin D (Mean \pm SD.) of patients was $17.8907 \pm 4.6069$. Difference of Mean Vitamin D vs. group was statistically significant $(p<0.0001)$ and in Study group, the Mean serum Ca (Mean \pm SD.) of patients was $6.8000 \pm .9672$. In comparative group, the Mean serum Ca (Mean \pm SD.) of patients was 9.6907 \pm .9218. Difference of Mean serum Ca vs. group was statistically significant $(\mathrm{p}<0.0001)$. We found that in Study group, the Mean serum Phosphorus

\begin{tabular}{|c|c|c|c|c|}
\hline \multicolumn{5}{|c|}{$\begin{array}{l}\text { Table 1. Distribution of Mean Age (years), Albu- } \\
\text { min, Total cholesterol, Final ht(cm), Final height } \\
\text { difference, Vitamin D, Serum Ca, Serum P, Serum } \\
\text { Mg and ALP. }\end{array}$} \\
\hline Variables & Group & Mean & SD & $\begin{array}{l}p- \\
\text { value }\end{array}$ \\
\hline \multirow[b]{2}{*}{$\begin{array}{l}\text { Age } \\
\text { (years) }\end{array}$} & Study group & 6.69 & 2.78 & \multirow[t]{2}{*}{0.61} \\
\hline & $\begin{array}{l}\text { Comparative } \\
\text { group }\end{array}$ & 6.45 & 2.81 & \\
\hline \multirow{2}{*}{ Albumin } & Study group & 2.27 & 1.86 & \multirow[t]{2}{*}{$\begin{array}{c}<0.00 \\
1\end{array}$} \\
\hline & $\begin{array}{l}\text { Comparative } \\
\text { group }\end{array}$ & 4.48 & 0.66 & \\
\hline \multirow{2}{*}{$\begin{array}{l}\text { Total } \\
\text { cholester- } \\
\text { ol }\end{array}$} & Study group & 332.95 & 55.2 & \multirow{2}{*}{$\begin{array}{c}<0.00 \\
1\end{array}$} \\
\hline & $\begin{array}{l}\text { Comparative } \\
\text { group }\end{array}$ & 166.68 & 18.4 & \\
\hline \multirow{2}{*}{$\begin{array}{l}\text { Final ht } \\
(\mathrm{cm})\end{array}$} & Study group & 114.30 & 18.6 & \multirow[b]{2}{*}{0.39} \\
\hline & $\begin{array}{l}\text { Comparative } \\
\text { group }\end{array}$ & 124.88 & 104.4 & \\
\hline \multirow{2}{*}{$\begin{array}{l}\text { Final } \\
\text { height } \\
\text { differ- } \\
\text { ence }\end{array}$} & Study group & 5.46 & 2.50 & \multirow[b]{2}{*}{0.78} \\
\hline & $\begin{array}{l}\text { Comparative } \\
\text { group }\end{array}$ & 5.36 & 1.97 & \\
\hline \multirow{2}{*}{$\begin{array}{l}\text { Vitamin } \\
\text { D }\end{array}$} & Study group & 12.63 & 3.50 & \multirow{2}{*}{$\begin{array}{c}<0.00 \\
1\end{array}$} \\
\hline & $\begin{array}{l}\text { Comparative } \\
\text { group }\end{array}$ & 17.89 & 4.61 & \\
\hline \multirow{2}{*}{$\begin{array}{l}\text { Serum } \\
\text { Ca }\end{array}$} & Study group & 6.80 & 0.97 & \multirow[t]{2}{*}{$\begin{array}{c}<0.00 \\
1\end{array}$} \\
\hline & $\begin{array}{l}\text { Comparative } \\
\text { group }\end{array}$ & 9.69 & 0.92 & \\
\hline \multirow[b]{2}{*}{ Serum P } & Study group & 5.21 & 1.00 & \multirow[t]{2}{*}{0.51} \\
\hline & $\begin{array}{l}\text { Comparative } \\
\text { group }\end{array}$ & 5.11 & 0.89 & \\
\hline \multirow{2}{*}{$\begin{array}{l}\text { Serum } \\
\text { Mg }\end{array}$} & Study group & 2.09 & 0.52 & \multirow[t]{2}{*}{0.24} \\
\hline & $\begin{array}{l}\text { Comparative } \\
\text { group }\end{array}$ & 2.00 & 0.44 & \\
\hline \multirow[b]{2}{*}{ ALP } & Study group & 136.32 & 66.36 & \multirow[t]{2}{*}{0.02} \\
\hline & $\begin{array}{l}\text { Comparative } \\
\text { group }\end{array}$ & 113.43 & 53.73 & \\
\hline
\end{tabular}

(Mean \pm SD.) of patients was $5.2147 \pm .9998$. In comparative group, the mean serum Phosphorus (Mean \pm SD.) of patients was 5.1135 \pm .8854 . Difference of mean serum Phosphorus vs. group was not statistically significant $(p=0.5145)$ and in Study group, the mean serum $\mathrm{Mg}$ (Mean $\pm \mathrm{SD}$.) of patients was $2.0947 \pm .5162$. In comparative group, the mean serum $\mathrm{Mg}(\mathrm{Mean} \pm \mathrm{SD}$.) of patients was $2.0027 \pm .4353$. Difference of mean serum $\mathrm{Mg}$ vs. group was statistically significant $(p=0.2399)$. It was found that in study group, the Mean ALP (Mean \pm SD.) of patients was $136.3200 \pm 66.3598$. In comparative group, the mean ALP (Mean \pm SD.) of patients was $113.4267 \pm 53.7341$ (Table 1). Difference of mean ALP vs. group was statistically significant $(\mathrm{p}=0.0216)$.

\section{DISCUSSION}

We found that in study group, the mean age (Mean $\pm \mathrm{SD}$ ) of patients was $6.6867 \pm 2.7751$ years. In comparative group, the mean age (Mean $\pm \mathrm{SD}$ ) of patients was $6.4533 \pm 2.8119$ years. Difference of mean age vs. group was not statistically significant $(p=0.6098)$. Present study found that the mean age at diagnosis (Mean \pm SD) of patients was $5.4067 \pm$ 2.4143 years. Association of sex vs. group was not statistically significant $(\mathrm{p}=0.3968)$.

Biyikli et al, ${ }^{8}$ found that serum ALP, OC, and iPTH levels were within normal limits at the time of study entry. However, both serum OC and ALP levels showed a significant decrease after the completion of CS treatment (OC from 13.6 $\pm 9.2 \mathrm{ng} /$ $\mathrm{ml}$ to $6.7 \pm 5.2 \mathrm{ng} / \mathrm{ml}$ and ALP from $151.8 \pm 60.2 \mathrm{U} / 1$ to $116 \pm 43.8 \mathrm{U} / 1)$. 25-Hydroxyvitamin $\mathrm{D}$ levels increased to $17.2 \pm 8.9 \mathrm{microg} / \mathrm{l}$ from $9.9 \pm 6.9$ microg/1 after CS treatment. The effects of recurrent use of CSs were assessed by dividing nephrotic patients into two subgroups: infrequent relapsers (IFR) and frequent relapsers (FR). The cumulative dose of CS was $28,125 \mathrm{mg} / \mathrm{m}(2)$ for IFR and $105,000 \mathrm{mg} / \mathrm{m}(2)$ for FR. The changes in OC, ALP, and 25-hydroxyvitamin D levels after CS treatment were significantly different between IFR and FR.

We found that in study group, the mean albumin (Mean \pm SD) of patients was $2.2733 \pm 1.8598 \mathrm{mg} /$ dl. In comparative group, the mean albumin $($ Mean \pm SD.) of patients was $4.4847 \pm .6601 \mathrm{mg} / \mathrm{dl}$. Difference of mean albumin vs. group was statistically significant $(\mathrm{p}<0.001)$.

Present study found that in study group, the mean ALP (Mean \pm SD.) of patients was $136.3200 \pm$ 66.3598. In comparative group, the mean ALP $($ Mean \pm SD) of patients was $113.4267 \pm 53.7341$. Difference of mean ALP vs. group was statistically significant $(\mathrm{p}=0.0216)$. 
We found that in study group, the mean total cholesterol (Mean \pm SD) of patients was $332.94 \pm$ $55.2940 \mathrm{mg} / \mathrm{dl}$. In comparative group, the mean total cholesterol (Mean \pm SD) of patients was $166.6800 \pm 18.4707 \mathrm{mg} / \mathrm{dl}$. Difference of mean total cholesterol vs. group was statistically significant $(\mathrm{p}<0.001)$.

In study group, the mean final height (Mean $\pm \mathrm{SD})$ of patients was $114.2960 \pm 18.5996 \mathrm{~cm}$. In comparative group, the mean final height (Mean \pm SD) of patients was $124.8773 \pm 104.4226 \mathrm{~cm}$. Difference of Mean Final ht vs. group was not statistically significant $(p=0.3890)$. We found that in study group, the mean final height difference (Mean \pm SD) of patients was $5.4613 \pm 2.4978$. In comparative group, the mean final height difference $($ Mean \pm SD) of patients was $5.3573 \pm 1.9650$. Difference of mean final height difference vs. group was not statistically significant $(\mathrm{p}=0.7773)$. According to final height difference in study group, $4(5.3 \%)$ patients had $\geq-2$ to $<+2$ and 71 (94.7\%) patients had $\geq+2$. According to final height difference in comparative group, 3(4.0\%) patients had $\geq-2$ to $<+2$ and $72(96.0 \%)$ patients had $\geq+2$. Association of final height difference vs. group was not statistically significant $(\mathrm{p}=0.6986)$.

Koşan et al ${ }^{9}$ found that mean serum calcium (Ca) and osteocalcin levels were found to be significantly lower than those at the beginning of the therapy. Mean serum total alkaline phosphatase (t-ALP), bone-specific alkaline phosphatase (b-ALP) and urine calcium creatinine ratio $(\mathrm{Ca} / \mathrm{Cr})$, urinary deoxypyridinoline levels were significantly increased in comparison to the beginning of therapy. There was no significant relationship between serum levels of phosphate and parathyroid hormone $(\mathrm{PTH})$ at the beginning of treatment and at the 4 th and 12 th week of treatment.

We found that in study group, the mean Vitamin $\mathrm{D}($ Mean $\pm \mathrm{SD})$ of patients was $12.6293 \pm 3.4974$. In comparative group, the mean Vitamin D (Mean \pm SD) of patients was $17.8907 \pm 4.6069$. Difference of mean Vitamin D vs. group was statistically significant $(p<0.0001)$. Present study found that in study group, the mean serum $\mathrm{Ca}$ (Mean $\pm \mathrm{SD}$ ) of patients was $6.8000 \pm .9672$. In comparative group, the mean serum $\mathrm{Ca}$ (Mean \pm SD.) of patients was
$9.6907 \pm .9218$. Difference of mean serum Ca vs. group was statistically significant $(\mathrm{p}<0.001)$.

Present study found that in study group, the mean serum P (Mean \pm SD) of patients was 5.2147 \pm .9998. In comparative group, the mean serum $\mathrm{P}$ (Mean \pm SD.) of patients was $5.1135 \pm .8854$. Difference of mean serum P vs. group was not statistically significant $(\mathrm{p}=0.5145)$. Present study found that in study group, the mean serum $\mathrm{Mg}$ (Mean \pm SD) of patients was $2.0947 \pm .5162$. In comparative group, the mean serum $\mathrm{Mg}$ (Mean \pm SD) of patients was $2.0027 \pm .4353$. Difference of mean serum $\mathrm{Mg}$ vs. group was statistically significant $(\mathrm{p}=0.2399)$. In Study group, 64(85.3\%) patients had relapse 1 and $11(14.7 \%)$ patients had relapse 2 .

Mohamed et al, ${ }^{10}$ found that alkaline phosphatase (ALP), and 24- hour urinary $\mathrm{Ca}$ and proteins were measured. The NS patients revealed a significantly lower serum OPG and parameters of bone formation (ALP and OC) and a significantly higher 24- hour urinary $\mathrm{Ca}$ than comparative groups. A short course of glucocorticoids therapy for one month resulted in a significant decrease of serum OPG, ALP and OC levels and a significant increase of 24- hour urinary $\mathrm{Ca}$, while serum PTH levels were not significantly affected by this therapy; the FR revealed a significantly lower serum level and a significantly higher 24- hour urinary $\mathrm{Ca}$ and serum PTH than the IFR. OPG had significant negative correlations with markers of disease activity and severity (ESR, serum cholesterol, 24- hour urinary protein and cumulative steroid dose), PTH and 24hour urinary $\mathrm{Ca}$. On the other hand, OPG had significant positive correlations with ALP, OC, and serum albumin.

\section{CONCLUSIONS}

We found that the mean albumin significant lower in study group compared to comparative group but mean ALP significant higher in study group. It was also found that total cholesterol was significantly higher in study group.

\section{Limitations of the study}

This study is conducted by taking small sample size in a single center hospital so finding of this study cannot be generalized to all the population.

REFERENCES
1. "Nephrotic Syndrome in Adults". National
Institute of Diabetes and Digestive and Kidney
Diseases. February 2014. Retrieved 9 November
2017 .
2. Ferri, Fred F. (2017). Ferri's Clinical Advisor
2018 E-Book: 5 Books in 1. Elsevier Health
Sciences.p. 889.ISBN 9780323529570.
3. Kher, Kanwal; Schnaper, H. William;

Greenbaum, Larry A. (2016). Clinical Pediatric Nephrology, Third Edition. CRC Press.p. 307.ISBN 9781482214635.

4. Kelly, Christopher R.; Landman, Jaime (2012).The Netter Collection of Medical Illustrations - Urinary System e-Book.Elsevier Health Sciences.p. 101.ISBN 1455726567.

5. Behrman, Richard E.; Robert M Kliegman; Hal B. Jenson (2008).NelsonTratado de Pediatria (in 
Spanish). Elsevier, España. p. 1755.ISBN 8481747475.

6. "Electronic Learning Module for Kidney and Urinary Tract Diseases".Archived from the original on 2008-12-20. Retrieved 2015-12-25.

7. Freedberg, Irwin M. et.al, ed. (2003). Fitzpatrick's dermatology in general medicine (6th ed.). New York, NY [u.a.]: McGraw-Hill. p. 659.ISBN 0-07-138076-0.

8. Biyikli NK, Emre S, SirinA, Bilge I. Biochemical bone markers in nephrotic children. Pediatric Nephrology. 2004 Aug 1;19(8):869-73.
9. Koşan C, Ayar G, Orbak Z. Effects of steroid treatment on bone mineral metabolism in children with glucocorticoid-sensitive nephrotic syndrome. West Indian Medical Journal. 2012 Sep;61(6):627-30.

10. Mohamed GB, Abdel-Latif EA. Serum osteoprotegerin (OPG) in children with primary nephrotic syndrome. Saudi Journal of Kidney Diseases and Transplantation. 2011 Sep 1;22 (5):955.

Citation: Pan A, Jana D. Relation of Steroid on Linear Growth Velocity with Biochemical Bone Markers in Children with Nephrotic Syndrome in a Teaching Hospital, Central Nepal. JCMS Nepal. 2020; 16(1):49-53. 